Supporting information

\title{
An Ambient Temperature Molten Sodium-Vanadium Battery with Aqueous Flowing Catholyte
}

\author{
Caihong Liu, ${ }^{a, b}$ Jack S. Shamie, ${ }^{a, b}$ Leon L. Shaw, ${ }^{a, b,{ }^{*}}$ Vincent L. Sprenkle ${ }^{c}$ \\ a Wanger Institute for Sustainable Energy Research \\ ${ }^{\mathrm{b}}$ Department of Mechanical, Materials and Aerospace Engineering \\ Illinois Institute of Technology, Chicago, Illinois 60616 \\ c Energy Storage and Conversion Energy Materials \\ Pacific Northwest National Laboratory, Richland, WA 99352
}

* Corresponding author: Ishaw2@iit.edu 
- NaCs vs NaK alloy
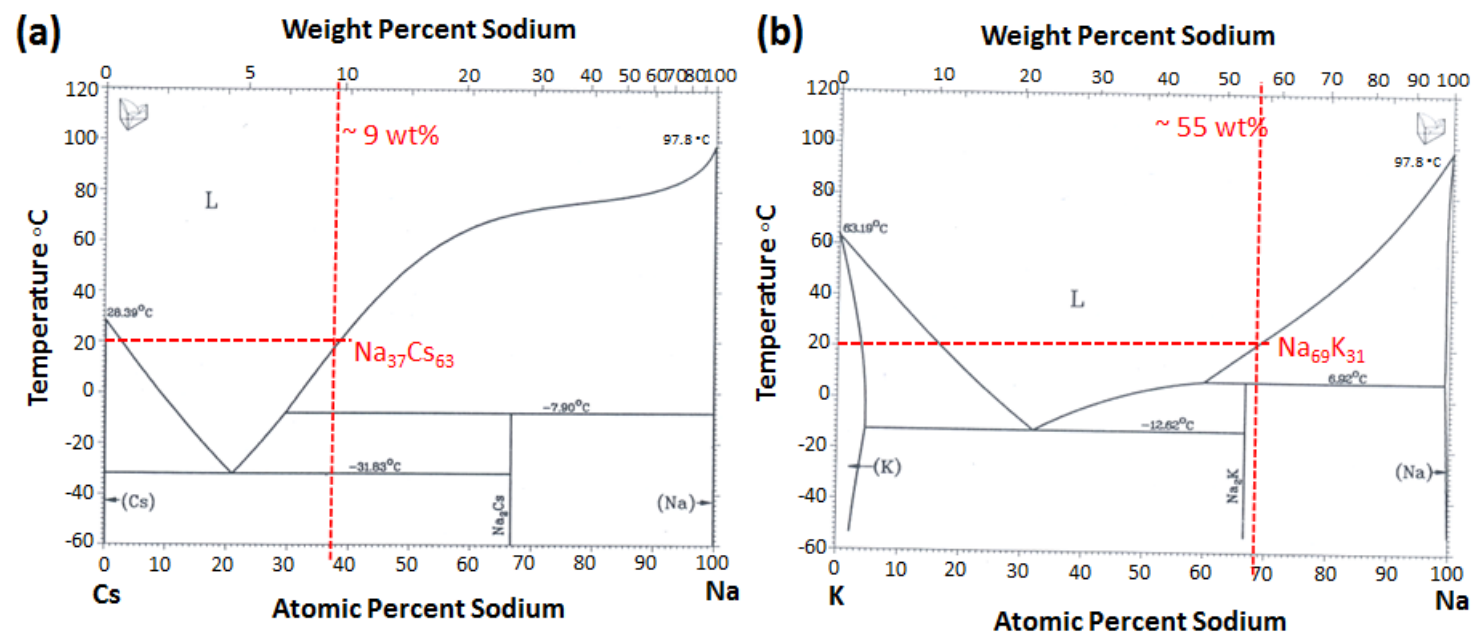

Figure S1: Phase diagrams of (a) Na-Cs and (b) Na-K. ${ }^{1}$ 


\section{- Functionalization of graphite felts}

- Thermal treatment
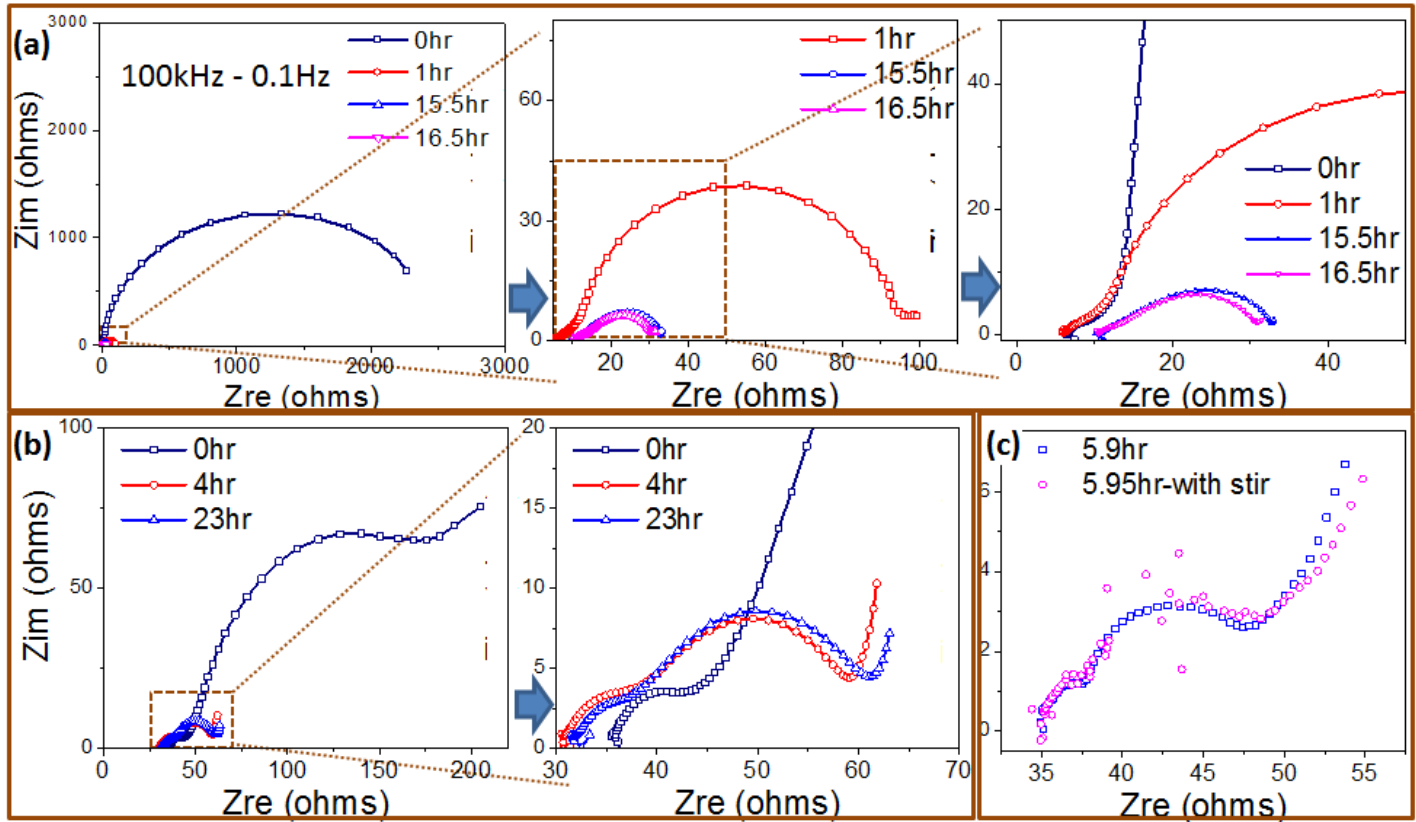

Figure S2. Nyquist plots evolution of $0.05 \mathrm{M} \mathrm{VOSO}_{4}-0.1 \mathrm{M} \mathrm{Na}_{2} \mathrm{SO}_{4}$ electrolyte obtained on different graphite felts (SGL group) working electrodes: graphite felt GFD4.6 after annealed in air for 1.5 hours (a) and 7.5 hours (b), GFD5.0 annealed for 7.5 hours in air (c). EIS were performed at OCV of the cell from 3-electrode setup where Pt wire, $\mathrm{Ag} / \mathrm{AgCl}$ electrode, and graphite felts were served as counter, reference, and working electrodes. A sinusoidal signal with amplitude of $10 \mathrm{mV}$ was applied to the cell. The frequency of the signal was scanned from $100 \mathrm{kHz}$ to $0.1 \mathrm{~Hz}$.

Figure S2 illustrated the nyquist plots of $\mathrm{VOSO}_{4}$ electrolyte on GFD4.6 annealed for 1.5 hour, 7.5 hour, and GFD5.0 treated for 7.5 hour, respectively. All these nyquist plots exhibit two semicircle features which correspond to charge transfer and interfacial capacitance/resistance. It can be seen that after 7.5 hour anneal, the resistance is much smaller than that from GFD4.6 annealed 1.5 hours. The drop of the resistance is mainly attributed to the improved wetting and increased contact area on interface of aqueous electrolyte/graphite felt. Meanwhile, it's much faster to reach the best contact/wetting on 7.5 hour annealed graphite felts which takes several hours, instead of over 16 hours on the graphite felts annealed 1.5 hours. The oxidation on the graphite felts during the anneal either results in decreased electrode conductivity, showing larger $R_{e}$ in the case of 7.5 hour-annealed graphite felts. These results indicated that the thermal treatments on graphite felts can dramatically improve the wetting hence the impedence were redued and stabilized much faster. 
- Catalyst decoration: effect of $\mathrm{BiCl}_{3}$

(a)

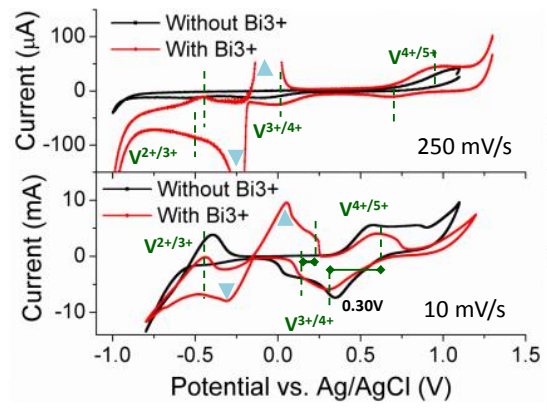

(b)

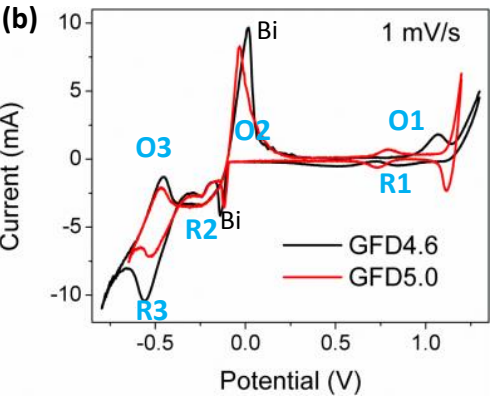

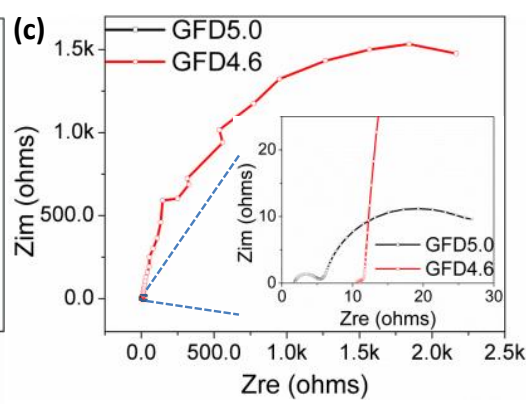

Figure S3. Electrochemical study of catalytic effect of $\mathrm{Bi}$ on SGL graphite felts in $0.05 \mathrm{M} \mathrm{VOSO} \mathrm{VO}_{4}-1 \mathrm{M}$ $\mathrm{Na}_{2} \mathrm{SO}_{4}-0.002 \mathrm{M} \mathrm{BiCl}_{3}-1.5 \mathrm{M} \mathrm{HCl}$ electrolyte. 3-electrode setup were used to perform the $\mathrm{CV}$ (a) and EIS (b) tests, in which graphite felts, $\mathrm{Ag} / \mathrm{AgCl}$, and Pt wire were working, reference, counter electrodes. The EIS were recorded after the electrodes soaked in solution for ca 4.5 hours.

The catalytic effect of $\mathrm{Bi}$ were explored on CM GF, GFD4.6 and GFD5.0 GFs after 5 hour thermal treatment (as shown in Figure S3). In CV spectra, the corresponding redox peaks of $\mathrm{V}^{2+} \beta^{3+}, \mathrm{V}^{3+} /^{4+}, \mathrm{V}^{4+} /^{5^{+}}$have been labeled in Figure $3 \mathrm{a}$. $\mathrm{R} 1, \mathrm{R} 2, \mathrm{R} 3$ in Figure $3 \mathrm{~b}$ are to the reduction peaks of $\mathrm{V}^{5+/ 4+}, \mathrm{V}^{4+/ 3+}$, and $\mathrm{V}^{3+/ 2+}$, respectively. And $\mathrm{O} 1, \mathrm{O} 2, \mathrm{O} 3$ are the corresponding oxidation peaks. The filled triangles marked the redox peaks of $\mathrm{Bi} / \mathrm{Bi}^{3+}$. Narrower potential discrepency were observed in $\mathrm{V}^{4+} / \mathrm{V}^{5+}$ and $\mathrm{V}^{3+} / \mathrm{V}^{4+}$ redox couples on $\mathrm{CM}$ GF with $\mathrm{BiCl}_{3}$ in the electrolyte, implying active catalytic effect on these two redox reactions. While, significant improvements on $\mathrm{V}^{2+} \mathrm{N}^{3+}$ redox were observed both on GFD4.6 and GF5.0 compared the one without $\mathrm{BiCl}_{3}$ shown in Figure 2. No obvious effect on $\mathrm{V}^{3+} / \mathrm{V}^{4+}$ and $\mathrm{V}^{4+} / \mathrm{V}^{5+}$ redox couples can be found on GFD5.0 from $\mathrm{CV}$ test though smaller impedance than that without $\mathrm{Bi}$ was detected. The results on GFD5.0 is exactly same as literature reported by B. Li, et. al.. ${ }^{2}$ However, adverse influence to $\mathrm{V}^{4+} \mathrm{V}^{5+}$ redox couples and positive effect on $\mathrm{V}^{3+} / \mathrm{V}^{4+}$ couple showed on GFD4.6 in comparison with the one without $\mathrm{Bi}$. Moreover, the dramatically raised impedance at OCV further implys negative effect towards $\mathrm{V}^{4+} / \mathrm{V}^{5+}$ redox since the OCV is only close to $\mathrm{V}^{4+} / \mathrm{V}^{5+}$ redox reactions. Besides, the addition of $\mathrm{Bi}$ changes the potential of each redox reactions, especially on GFD4.6 electrodes. Overall, these GFs showed dramatically different response pattern towards the presense of Bi catalyst. 
- Raman Analysis

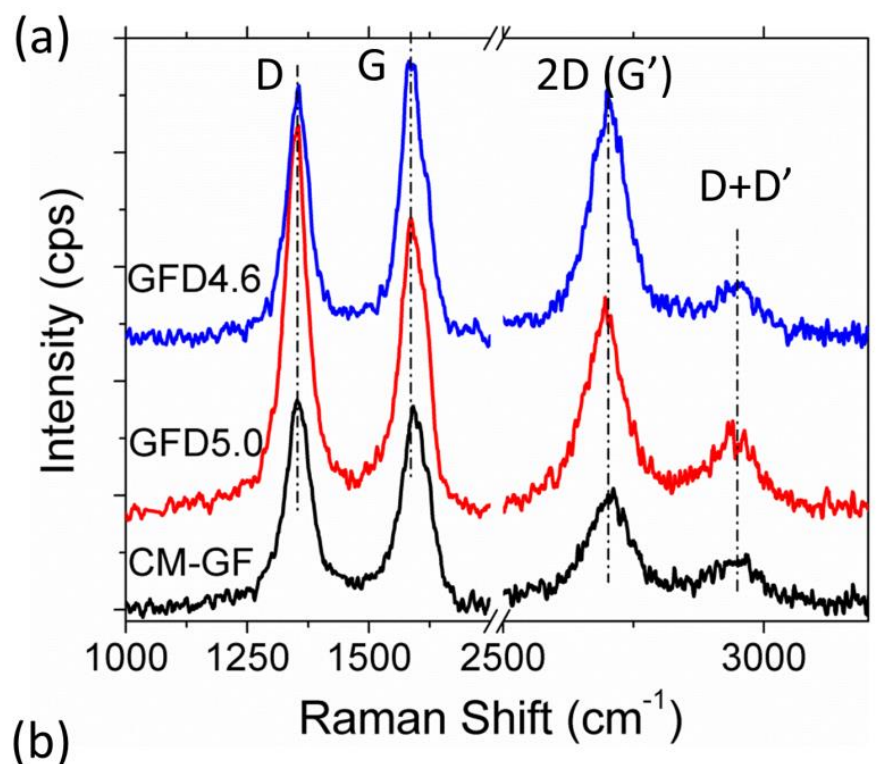

(b)

\begin{tabular}{|c|c|c|c|}
\hline Sample & CM-GF & GFD4.6 & GFD5.0 \\
\hline $\mathrm{I}_{\mathrm{D}} / \mathrm{I}_{\mathrm{G}}$ & 1.03 & 0.91 & 1.31 \\
\hline
\end{tabular}

Figure S4. Raman spectra of the graphite felts after thermal treatment.

All the graphite felts as shown in Figure S4a exhibited four peaks - the $D, G, 2 D\left(G^{\prime}\right)$, and $D+D^{\prime}$ band at around $1356 \mathrm{~cm}^{-1}, 1587 \mathrm{~cm}^{-1}, 2697 \mathrm{~cm}^{-1}$, and $2950 \mathrm{~cm}^{-1}$, respectively. ${ }^{3-5}$ Among them, $G$ and $2 D\left(G^{\prime}\right)$ are attributed to the in-plane $s^{2}$ vibration, while $D$ and $D+D^{\prime}$ band are related with disorder/defects and hydrogenated carbon scattering. ${ }^{3-5}$ The intensity ratio of the $D$ band to $G$ band $\left(I_{D} / I_{G}\right)$ is used as an index to evaluate the defect density as shown in Figure S4b. GFD5.0 graphite felts have a higher $I_{D} / l_{G}$ than the other two types of graphite felts as well as a stronger $D+D$ ' band than the others. These results suggest more O-containing functional groups and $\mathrm{CH}_{3} /-\mathrm{CH}_{2-}$ on GFD5.0. They could act as catalytical sites for the $\mathrm{V}$ redox reaction during the cycling tests. 


\section{- Cycling performance of HNFBs with Ceramaterials GF}
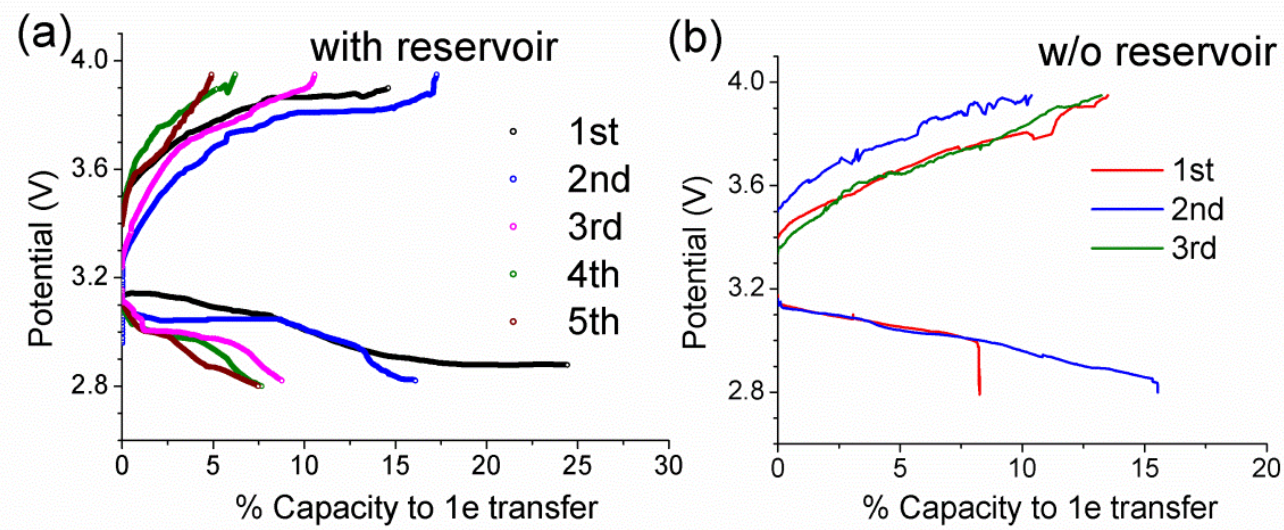

Figure S5. Potential-capacity profiles of Na-V hybrid batteries using CM GF as cathodic electrode and $0.05 \mathrm{M} \mathrm{VOSO}_{4}-1.5 \mathrm{M} \mathrm{Na}_{2} \mathrm{SO}_{4}-3.0 \mathrm{M} \mathrm{HCl}$ catholyte flowing through with reservoir (a) and without reservoir (b). The cells were cycled between $3.95 \mathrm{~V}$ and $2.8 \mathrm{~V}$ at $50 \circ \mathrm{C}$.

The cell illustrated in Figure S5 has a composition of CM GF (5hr annealed)/0.05 M VOSO $4-1.5$ $\mathrm{M} \mathrm{Na}_{2} \mathrm{SO}_{4} \mid \beta^{\prime \prime}-\mathrm{Al}_{2} \mathrm{O}_{3}$ (Mem B) | $\mathrm{Na}_{37} \mathrm{Cs}_{63} / \mathrm{Al}$ foam. The cycling test of the cell was carried out between 2.8 and $3.95 \mathrm{~V}$, in which only $\mathrm{V}^{4+} / \mathrm{V}^{5+}$ redox reaction occurred on GF. Higher overpotential were observed in above cells. Only $7-20 \%$ of SOC and DOS were obtained. It implied the importance on selection of graphite felts. 


\section{- Quantative equivalent circuit simulation on the membrane and full cells}

Table S1. Equivalent circuit simulation results for $\beta$ "- $\mathrm{Al}_{2} \mathrm{O}_{3}$ membranes shown in Figure 6 in which circuit $R(Q(R(Q(R(C R)))))$ was utilized.

\begin{tabular}{ccccc}
\hline Samples & $\begin{array}{c}\text { Mem A } \\
\text { (used for 2 } \\
\text { months) }\end{array}$ & $\begin{array}{c}\text { Mem B } \\
\text { (new) }\end{array}$ & $\begin{array}{c}\text { Mem C } \\
\text { (new) }\end{array}$ & $\begin{array}{c}\text { Mem D } \\
\text { (new) }\end{array}$ \\
\hline$R_{e}(\Omega)$ & 30.41 & 5.855 & 10.05 & 6.43 \\
$R_{\text {ct }}(\Omega)$ & 875.9 & 64.97 & 84.3 & 59.6 \\
$R_{\text {gb }}(\Omega)$ & $344.1 \mathrm{k}$ & 374.4 & 228.4 & 501.1 \\
$\mathrm{R}_{\text {int }}(\Omega)$ & 1601 & 56.34 & 74.0 & 1.001 \\
$\begin{array}{c}\sigma(\mathrm{S} / \mathrm{cm}, \text { based } \\
\left.\text { on } \mathrm{R}_{\mathrm{gb}}\right)^{\mathrm{a}}\end{array}$ & $1.34 \times 10^{-6}$ & $9.84 \times 10^{-5}$ & $1.61 \times 10^{-4}$ & $7.35 \times 10^{-5}$ \\
\hline
\end{tabular}

aThe ionic conductivity $\sigma$ is calculated according to equation $\sigma=\frac{l}{\operatorname{Rgb} \cdot \mathrm{A}}$, where $/$ and $A$ are the thickness and area of solid electrolyte.

Table S2. Equivalent circuit simulation results for Figure 7 in which circuit $R(Q(R(Q(R(C R)))))$ was utilized.

\begin{tabular}{|cccccc}
\hline Samples & $\begin{array}{c}\text { Mem C } \\
\text { only }\end{array}$ & $\begin{array}{c}\text { Fresh full } \\
\text { battery } \\
\text { (flowing) }\end{array}$ & $\begin{array}{c}\text { Charged } \\
\text { 70h_stopped } \\
\text { flowing }\end{array}$ & $\begin{array}{c}\text { Charged } \\
\text { 70h_reflowing }\end{array}$ \\
\hline$R_{\mathrm{e}}(\Omega)$ & 10.05 & 81.3 & 30.64 & 29.6 \\
$\operatorname{R}_{\mathrm{ct}}(\Omega)$ & 84.3 & 205.7 & 433.1 & 258.6 \\
$\operatorname{R}_{\mathrm{gb}}(\Omega)$ & 228.4 & 1711 & 1981 & 2018 \\
$\operatorname{R}_{\text {int }}(\Omega)$ & 74.0 & 364.8 & 4734 & 4026 \\
\hline
\end{tabular}

\section{References}

(1) Massalski, T. B.; Murray, J. L.; Bennett, L. H.; Baker, H. (ed.) Binary Alloy Phase Diagrams, ASM international, Materials Park, $\mathrm{OH}$.

(2) Li, B.; Gu, M.; Nie, Z.; Shao, Y.; Luo, Q.; Wei, X.; Li, X.; Xiao, J.; Wang, C.; Sprenkle, V.; Wang, W. Bismuth Nanoparticle Decorating Graphite Felt as a High-Performance Electrode for an All-Vanadium Redox Flow Battery. Nano Lett. 2013, 13, 1330-1335.

(3) Ferrari, A. C.; Meyer, J. C.; Scardaci, V.; Casiraghi, C.; Lazzeri, M.; Mauri, F.; Piscanec, S.; Jiang, D.; Novoselov, K. S.; Roth, S.; Geim, A. K. Raman Spectrum of Graphene and Graphene Layers. Phys. Rev. Lett. 2006, 97, 187401. 
(4) Reich, S.; Thomsen, C. Raman Spectroscopy of Graphite. Philos. Trans. A. Math. Phys. Eng. Sci. 2004, 362, 2271-2288.

(5) Elias, D. C.; Nair, R. R.; Mohiuddin, T. M. G.; Morozov, S. V; Blake, P.; Halsall, M. P.; Ferrari, A. C.; Boukhvalov, D. W.; Katsnelson, M. I.; Geim, A. K.; Novoselov, K. S. Control of Graphene's Properties by Reversible Hydrogenation: Evidence for Graphane. Science 2009, 323, 610-613. 